\title{
Casing failure identification of long-abandoned geothermal wells in Field Dieng, Indonesia
}

\author{
B. T. H. Marbun ${ }^{1 *} \mathbb{E}$, R. H. Ridwan², S. Z. Sinaga', B. Pande ${ }^{1}$ and B. A. Purbantanu'
}

\author{
*Correspondence: \\ bonar.marbun@tm.itb.ac.id \\ ${ }^{1}$ Petroleum Engineering \\ Study Program, Bandung \\ Institute of Technology, Jalan \\ Ganesha 10, Bandung 40132, \\ Indonesia \\ Full list of author information \\ is available at the end of the \\ article
}

\begin{abstract}
Integrity issues create challenges for maintaining the production of mature geothermal wells. Such problems are likely to occur in wells designed according to oil and gas standards, without considering the extreme geothermal environment. PT Geo Dipa Energi as the operator of the Dieng geothermal field, one of the longest operated in Indonesia, has experienced this difficulty since acquiring the field. Almost half of the production wells have been abandoned because of casing issues. To increase production, the operator plans to reactivate wells that have been previously abandoned. An initial study was performed to assess the technical feasibility of reactivating wells at Dieng; it included the development of a well assessment methodology including casing design, comprising historical data analysis, identification of well problems, and investigation of well integrity. The study focused on the identification and characterization of two abandoned wells, HCE9B and HCE28B, current casing conditions, limitations, and challenges to perform a well intervention and workover which is realistic, measurable, economic, and technically feasible. The result of this study will be applicable for casing design for future wells.
\end{abstract}

Keywords: Geothermal wellbore, Well integrity, Casing design, Casing failure

\section{Introduction}

The effective lifetime of geothermal wells in Indonesia is approximately 20 years (Marbun et al. 2013). It becomes a crucial challenge for operators to maintain the well lifetime expectancy, especially for companies who operate mature geothermal fields. It is very common to encounter well problems and integrity issues in mature geothermal wells such as corrosion, scaling, casing failure, and cement damage, since they were designed using conventional oil and gas well approach without fully considering extreme geothermal environment (e.g., high temperature, corrosive fluids, hard rocks, etc.) and not always following general geothermal standard operating procedure (SOP) (Kaldal et al. 2015; Pellet 2017). One of the mature geothermal fields in Indonesia, Field Dieng, which has been operated for more than 20 years (Darma 2016), currently faces such problems. Among a total of 14 production wells, 5 wells were shut-in more than 6 years ago, while the remaining wells are still producing at a declining rate. Wellbore plugging due to silica scaling $\left(\mathrm{SiO}_{2}\right)$ occurred, both in abandoned and producing wells. In addition, such

(c) The Author(s) 2019. This article is distributed under the terms of the Creative Commons Attribution 4.0 International License (http://creativecommons.org/licenses/by/4.0/), which permits unrestricted use, distribution, and reproduction in any medium, provided you give appropriate credit to the original author(s) and the source, provide a link to the Creative Commons license, and indicate if changes were made. 
problems occurred because of the lack of knowledge and experience in the first development phase.

To increase the steam production capacity, PT Geo Dipa Energi considered two options: drilling new wells or reactivating the mature abandoned geothermal production wells. Based on studies of geothermal exploration and development drilling in Indonesia, drilling new wells requires considerable expenditure with various assumptions such as success ratio, technical factors, economic factors, administrative permit, and regulations (Wahjosoedibjo and Hasan 2018; Purwaningsih et al. 2017). On the contrary, other studies have showed that reactivating abandoned wells, including abandoned oil and gas wells, would be beneficial for the geothermal project and would cost less than drilling new wells if the reopening is performed correctly (Caulk and Tomac 2017; Røksland et al. 2017; Nian and Cheng 2018a, b; Capuano Jr. 2016). Based on the preliminary study, two abandoned wells could potentially produce steam up to 27.2 MW. However, well integrity is a crucial aspect that must be evaluated before recommencing the production of the abandoned wells. In addition, abandoned wells have no access due to being plugged with silica scaling. Based on preliminary analysis, well intervention and workover operation with mechanical cleaning are being considered to gain access into the well and to assess the well integrity of the abandoned wells.

Planning well operation for geothermal wells, both drilling or well intervention and workover, is more challenging, especially for mature wells that have been shut-in for years. Aside from the extreme geothermal environment, studies performed by Marbun et al. (2013) in geothermal fields in Indonesia showed that non-productive time and cost overrun occurred, especially due to improper planning and management (Marbun et al. 2015). The well intervention and workover planning become more complex and very costly when the wells are not properly maintained and monitored before they stopped producing, which raises difficulties to identify the well problems (Thorhallsson 2003). Another challenge also arises in this study due to the limited availability of official data.

This paper introduces an initial geothermal well assessment methodology to identify the casing failure of long-abandoned geothermal wells before reactivating them. The study focuses on the application of the methodology on two abandoned production wells in Field Dieng, wells HCE9B and HCE28B. The selection of both wells was based on potential, historical production data, and pad location analysis. The output of this paper is a technical analysis of casing failure identification; the method will also be applied to other similar abandoned geothermal wells in Field Dieng in the future.

\section{Methodology and scope of work}

The study presents a comprehensive methodology of casing failure assessment of mature abandoned geothermal wells as part of well intervention and workover planning strategy. According to the limitation of data and the information of the current condition of the abandoned wells, a methodology was established in this study to address the following aspects:

1. Initial well integrity assessment.

2. Recalculation of well design, inclination and azimuth angle effect analysis.

3. Proposed well intervention and workover plan. 
Figure 1 shows the methodology of the study presented here. The official available data were limited: (1) initial well test data, (2) directional drilling and trajectory data, (3) initial pressure and temperature survey data, (4) well schematic data, (5) daily operational drilling report, (6) well intervention and workover historical data, and (7) production historical data. Critical necessary data were not available: (1) original well design (drilling and completion), (2) final well reports (drilling and completion), (3) service companies reports (e.g., directional, wireline logging, cementing, etc.), (4) geological report, (5) well historical data (well intervention and workover, well services, etc.), and (6) production historical data.

According to the common geothermal SOP and best engineering practices, casing condition is mandatory to be examined. Initial well integrity assessment is a crucial step to understand the current condition of the wells. In this field, wellbore problems and well integrity issues comprised scaling and casing failure. Silica and carbonate scaling are commonly found in the geothermal system (Thorhallsson 2006; McGee and Smith 2016; Von Hirtz 2016). However, this study only analyzed the silica scaling issue (PT Geo Dipa Energi 2019; Agustinus et al. 2018; Wahyudityo et al. 2013), since carbonate scaling issue had not been identified and analyzed qualitatively and quantitatively at the

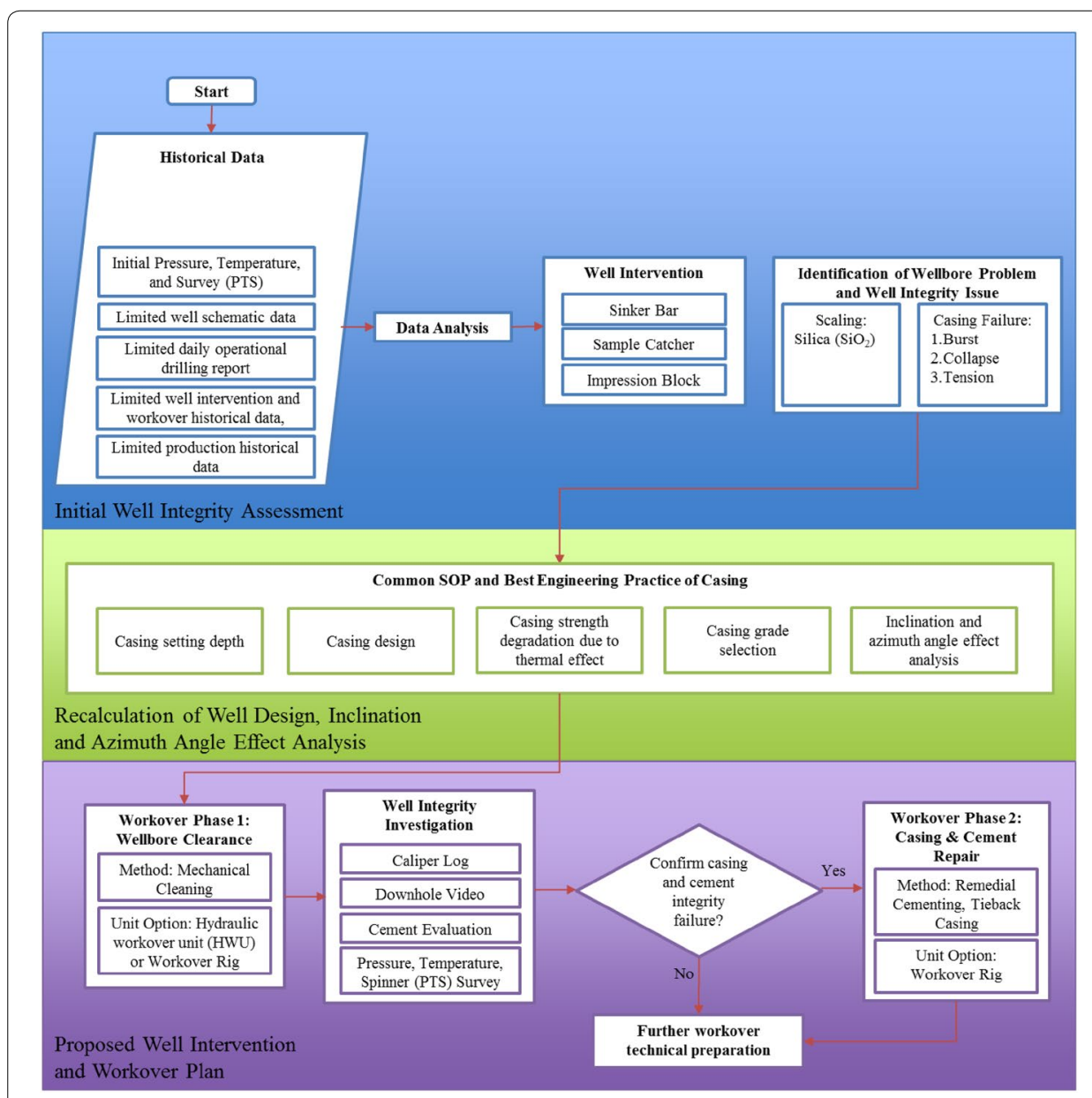

Fig. 1 The methodology of casing failure analysis for long-abandoned geothermal wells HCE9B and HCE28B 
beginning. Common casing failure mechanisms in geothermal wells include burst, collapse, and tension (Southon 2005). Cement damages such as crack, micro-annulus, and bad cementing, and corrosion are also common in geothermal wells which can lead to wellbore leakage. However, at the moment, cement damage and corrosion in the well cannot be investigated due to the wellbore being plugged by silica scale. In addition, cement evaluation data (e.g., cement bond $\log / \mathrm{CBL}$, variable density $\log / \mathrm{VDL}$, etc.) were not available, therefore, cement analysis was not performed in this study.

The wells were designed and drilled not according to common SOP and best engineering practice of geothermal drillings, such as the New Zealand Standard Code of Practice for Deep Geothermal Wells (Standards New Zealand 1991). The design of the wells and drilling operations was based on knowledge and experience gained in the oil and gas industry. Recalculation of well design for both wells was performed in this study. According to the well integrity issues encountered in this field and based on data and information limitation, following aspects that were not considered in the first phase of well development were analyzed in this study:

1. The high-temperature effect.

2. Thermal effect of the casing grade selection.

3. Inclination and azimuth angle effect.

Furthermore, the well intervention and workover plan were proposed following the study result.

\section{Field and wells overview}

Field Dieng is one of the mature volcanic geothermal fields in Central Java, Indonesia, which was developed in the 1990s (Marbun 2013; Darma 2016). Currently, the field is operated by PT Geo Dipa Energi (Sirait et al. 2015). The reservoir characteristic is a twophase hydrothermal system and dominated by water with a temperature range from 280 to $330{ }^{\circ} \mathrm{C}$ and a pressure range from 12.1 to $16.7 \mathrm{MPa}$. The fluid enthalpy ranges from 1300 to $2000 \mathrm{~kJ} / \mathrm{kg}$ and the production fluid contains silica up to $1200 \mathrm{ppm}$.

Initially, Field Dieng produced steam with capacity of $60 \mathrm{MW}$ (Asian Development Bank and The World Bank 2015; Sirait et al. 2015), but currently, the steam production decreased to approximately $20 \mathrm{MW}$. The geothermal unit with a capacity of $60 \mathrm{MW}$ was finished in 1998 and commercially started producing in 2002. 5 of 14 production wells were shut-in and temporarily abandoned due to a wellbore plugging issue. In addition, the wellbore plugging issue was also encountered in nine active production wells, causing production decrease. Technical and non-technical issues occur to other production and injection wells which also cause production decrease. Based on historical data, the wellbore plugging is caused by silica scale and it was aggravated by casing failure (Marbun 2013). In this study, two out of five abandoned wells were chosen to be evaluated and analyzed. Wells HCE9B and HCE28B were production wells drilled approximately more than 20 years ago. Based on initial production data, the well HCE9B has the potential to produce steam up to $15 \mathrm{MW}$, while well HCE28B has the steam production potential up to 12.2 MW (Marbun 2013). Figure 2 shows the trajectory of the two wells. Figure 3 shows the well schematic of the two wells. 

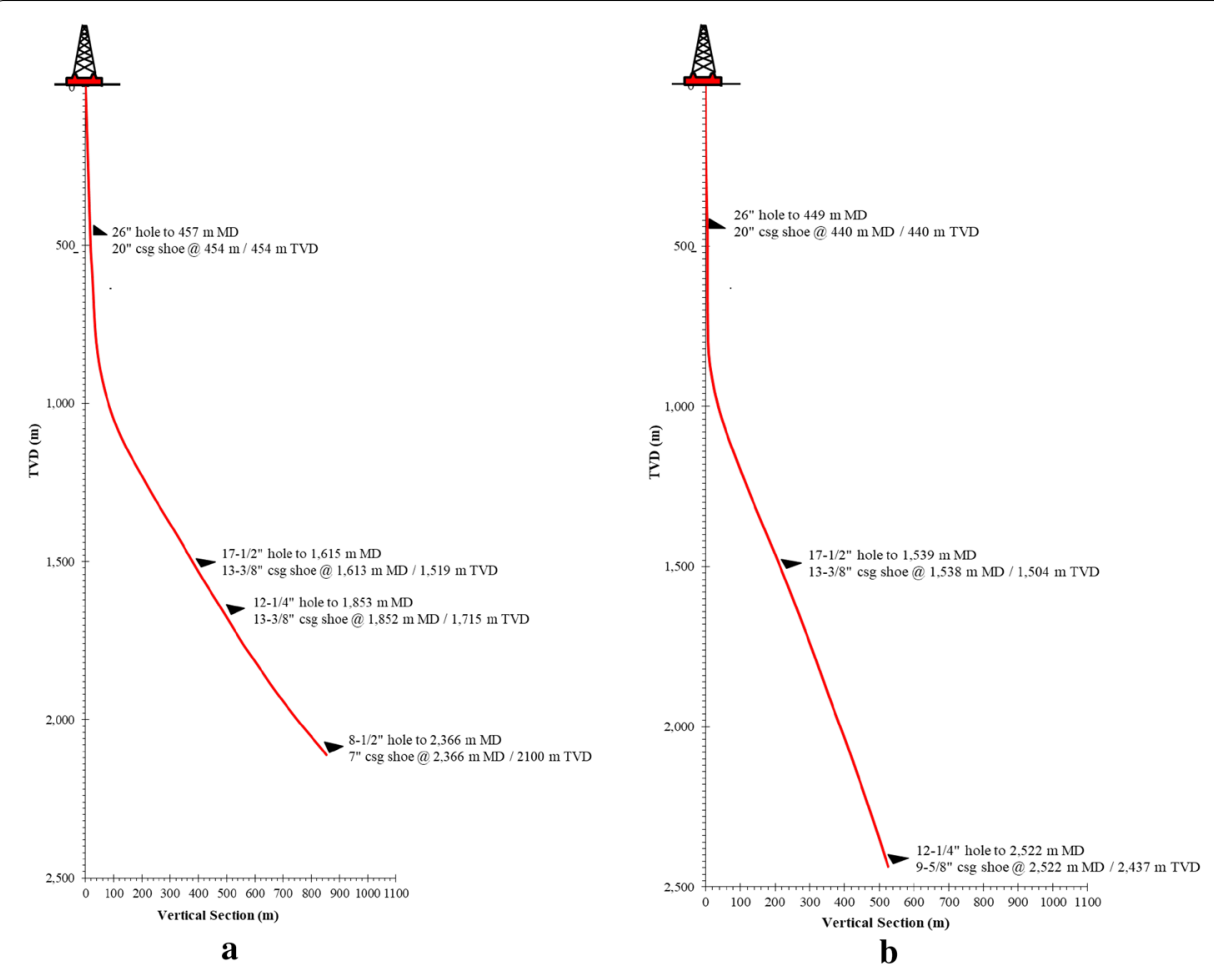

Fig. 2 Well trajectory of a HCE9B and b HCE28B (Marbun 2013; PT Geo Dipa Energi 2019)

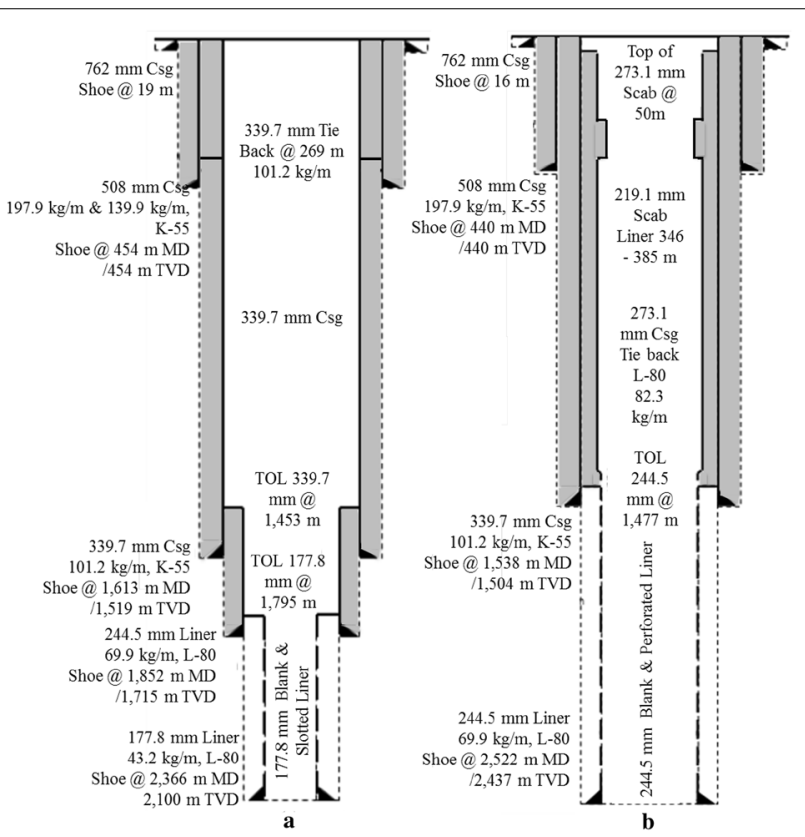

Fig. 3 Well schematic of a HCE9B and b HCE28B (Marbun 2013; PT Geo Dipa Energi 2019) 
Table 1 shows historical data of wells HCE9B and HCE28B including well design and drilling data, pressure and temperature survey, well intervention and workover history, and initial well integrity assessment. Due to the limited available official data, not all parts of the study could be properly performed. The original well design data were not available. Therefore, the well design was recalculated and evaluated to examine whether the well design could withstand the actual condition and the future workover plan. Based on well intervention and workover operations history, mechanical cleaning and tieback casing cementing were performed in wells HCE9B and HCE28B. The objective of the mechanical cleaning was to clean out the well from the silica scale, while the tieback casing was to repair the $508 \mathrm{~mm}$ casing collapse in well HCE9B and $339.7 \mathrm{~mm}$ casing collapse in well HCE28B.

\section{Review of well investigation}

Investigation of current well condition was conducted several times in wells HCE9B and HCE28B by running investigation tools (Marbun 2013, PT Geo Dipa Energi PT Geo Dipa Energi 2019). The investigation's objective was to assess the wellbore condition and identify the type of obstructions that blocked the steam to flow inside the wellbore to the surface. The following section describes the last mechanical investigation performed in the two abandoned wells.

In well HCE9B, a sample catcher with an outside diameter (OD) that ranged from 50.8 to $158.8 \mathrm{~mm}$ and length $0.67 \mathrm{~m}$ was run into the well at a maximum speed of $28 \mathrm{~m} /$ $\mathrm{min}$. The tool tagged at depth $523 \mathrm{~m}$. After jarring down operation, the tool successfully passed the obstruction and tagged at $542 \mathrm{~m}$, but further jarring down operation failed to pass the second obstruction at the $339.7 \mathrm{~mm}$ production casing section. It was decided to pull the tool out of the hole to obtain and analyze the sample from the catcher. At the surface, debris was recovered from the catcher. Based on the magnetic and X-ray diffraction test (XRD), it was confirmed that the debris contained metal. Based on this investigation, the metal debris recovered from the catcher was an indication of $339.7 \mathrm{~mm}$ production casing damage. Furthermore, the wellbore condition below $542 \mathrm{~m}$ remained unknown.

The recent well investigation for HCE28B was performed by running an $88.9 \mathrm{~mm}$ sample catcher and $152.4 \mathrm{~mm}$ impression block. The $88.9 \mathrm{~mm}$ sample catcher tagged the obstruction at $186 \mathrm{~m}$ and the tool could not pass through even after jarring down

Table 1 Pressure and temperature survey and well investigation data (Marbun 2013; PT Geo Dipa Energi 2019)

\begin{tabular}{lll}
\hline Data category & Well HCE9B & Well HCE28B \\
\hline Pressure and temperature survey & & \\
Initial static survey & $\checkmark$ & $\checkmark$ \\
Updated static survey & $\checkmark$ & $\checkmark$ \\
Well investigation & & \\
Sinker bar & $\checkmark$ & Yes, found silica debris \\
Sample catcher & Yes, found metal debris & Yes, found casing collapse marking \\
Impression block & Not performed &
\end{tabular}


operation. The tagged depth was inside $339.7 \mathrm{~mm}$ production casing. After pulling out of a hole, silica debris was recovered from the catcher. The XRD test confirmed that the sample contained amorphous silica of more than $50 \%$. The $152.4 \mathrm{~mm}$ impression block that was tagged at $185 \mathrm{~m}$ showed a mark on the edge of impression block that could indicate a $339.7 \mathrm{~mm}$ casing collapse. Based on this investigation at well HCE28B, the wellbore was blocked by silica scale and casing collapse most likely occurred at the $339.7 \mathrm{~mm}$ casing. However, the wellbore condition below $185 \mathrm{~m}$ remained unknown.

In summary, the well investigation conducted at wells HCE9B and HCE28B revealed that the wellbore was plugged inside the production casing. Silica scale deposition was indicated as the main obstruction in the two abandoned wells with an indication of casing failure. Table 2 shows a summary of the two abandoned wells condition.

\section{Result of casing failure evaluation based on casing design}

Casing design evaluation was performed to predict the casing failure mechanism in the two wells. The scope of casing design evaluation in this study focuses on casing setting depth and casing load analysis.

The two wells were designed using a conventional oil and gas approach by considering only depth, pore pressure, and fracture pressure without considering high thermal stress effect, lithology, and formation fluid. In spite of the similarity in the well construction process, high geothermal temperatures have a significant impact on the casing strength (Dench 1970; Capuano Jr. 2016). When the casing is exposed to the high-temperature environment, the strength decreases (Nicholson 1984). Moreover, the temperature changes in the well under dynamic condition (production and injection) and under static condition (shut-in) cause the well to experience compressiontension changes due to thermal loads, which lead to casing fatigue (Nicholson 1984). Figure 4 presents the initial temperature profile in the static condition of the two wells gathered from pressure and temperature survey after drilling. Ideally, the load calculation is based on the maximum temperature, however due to limitation of the data, the available temperature profile was used in this study. The temperature profile for well HCE9B was taken from pressure and temperature survey on 11 June 1997, while the temperature profile for well HCE28B was taken from pressure and temperature survey on 30 October 1997 (Marbun 2013; PT Geo Dipa Energi 2019). This temperature data were used in casing setting depth analysis and casing load calculation.

Table 2 Summary of well condition (Marbun 2013; PT Geo Dipa Energi 2019)

\begin{tabular}{|c|c|c|c|c|c|c|c|c|}
\hline Well & Total depth & $\begin{array}{l}\text { Final } \\
\text { inclination } \\
\left({ }^{\circ}\right)\end{array}$ & $\begin{array}{l}\text { Initial } \\
\text { production } \\
(\mathrm{MW})\end{array}$ & $\begin{array}{l}\text { Initial } \\
\text { production } \\
\text { year }\end{array}$ & $\begin{array}{l}\text { Current } \\
\text { condition }\end{array}$ & $\begin{array}{l}\text { Mechanical } \\
\text { cleaning } \\
\text { performed }\end{array}$ & $\begin{array}{l}\text { Remedial } \\
\text { casing }\end{array}$ & $\begin{array}{l}\text { Abandoned } \\
\text { year }\end{array}$ \\
\hline HCE9B & $\begin{array}{l}2366 \mathrm{~m} \\
\text { MD/2111 m } \\
\text { TVD }\end{array}$ & 41.5 & 15 & 1998 & $\begin{array}{l}\text { Plugged at } \\
542 \mathrm{~m}\end{array}$ & Yes & Yes & 2012 \\
\hline HCE28B & $\begin{array}{l}2522 \mathrm{~m} \\
\text { MD/2437 m } \\
\text { TVD }\end{array}$ & 17 & 12.2 & 1998 & $\begin{array}{l}\text { Plugged at } \\
185 \mathrm{~m}\end{array}$ & Yes & Yes & 2012 \\
\hline
\end{tabular}




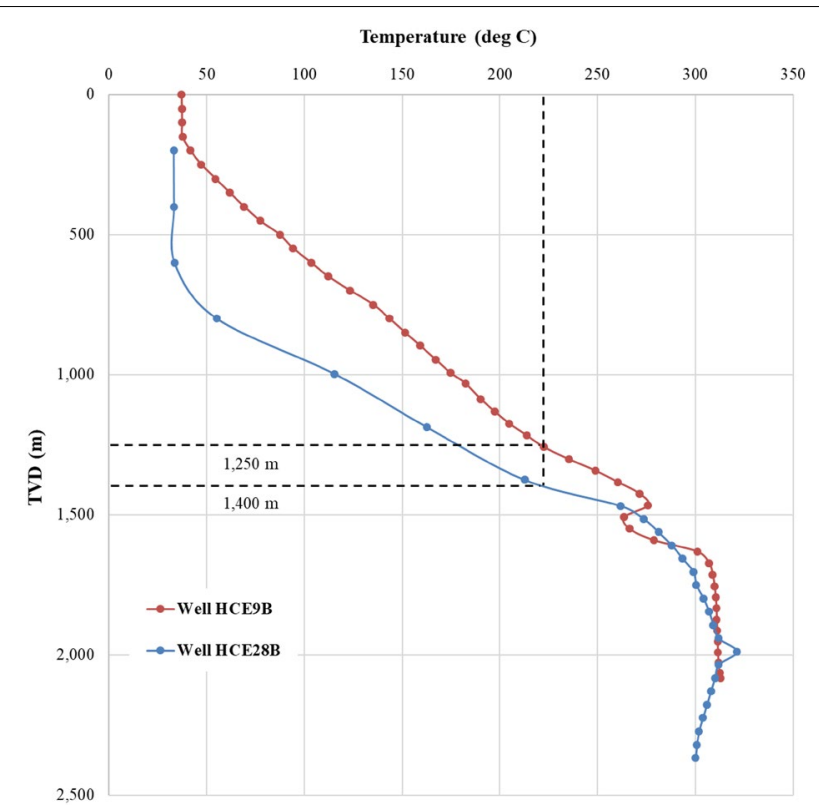

Fig. 4 The initial temperature profile of wells HCE9B and HCE28B in static condition (Marbun 2013; PT Geo Dipa Energi 2019)

\section{Casing setting depth analysis}

Three methods in determining casing setting depth for geothermal wells are common: New Zealand's method, Iceland's method, and the Philippines' method. New Zealand's method is used for reservoir dominated by steam with a reservoir temperature of more than $220^{\circ} \mathrm{C}$. It suggests that the boiling point curve is used as the lower limit, and the overburden pressure as the upper limit (Standards New Zealand 1991). Iceland's method is applied for two-phase geothermal wells with reservoir temperature more than $220^{\circ} \mathrm{C}$, and the determination of casing setting depth considers the well at the flowing state (Hossein-Pourazad 2005). In Iceland's method, the lower limit is the boiling point curve, and the hydrostatic mud/water is used as the upper limit. The Philippines' method is applied for a water-dominated geothermal reservoir with a reservoir temperature more than $220^{\circ} \mathrm{C}$. It suggests that the production casing is required to be set at the depth where the reservoir temperature attains $220^{\circ} \mathrm{C}$ (Sarmiento 2007). The purpose is to isolate the low-temperature formation fluid from high-temperature formation fluid. The pore pressure is used as the lower limit, while the overburden pressure is used as the upper limit.

In Field Dieng, the characteristic of the reservoir meets the Philippines' method requirement. Figure 5 shows the pressure and temperature profile of well HCE28B. Using this approach, the $339.7 \mathrm{~mm}$ production casing shoe for well HCE9B should be set at depth $1250 \mathrm{~m}$ TVD and the production casing shoe for well HCE28B should be set at $1400 \mathrm{~m}$ TVD. Figure 6 shows the example of casing setting depth determination for well HCE28B. 


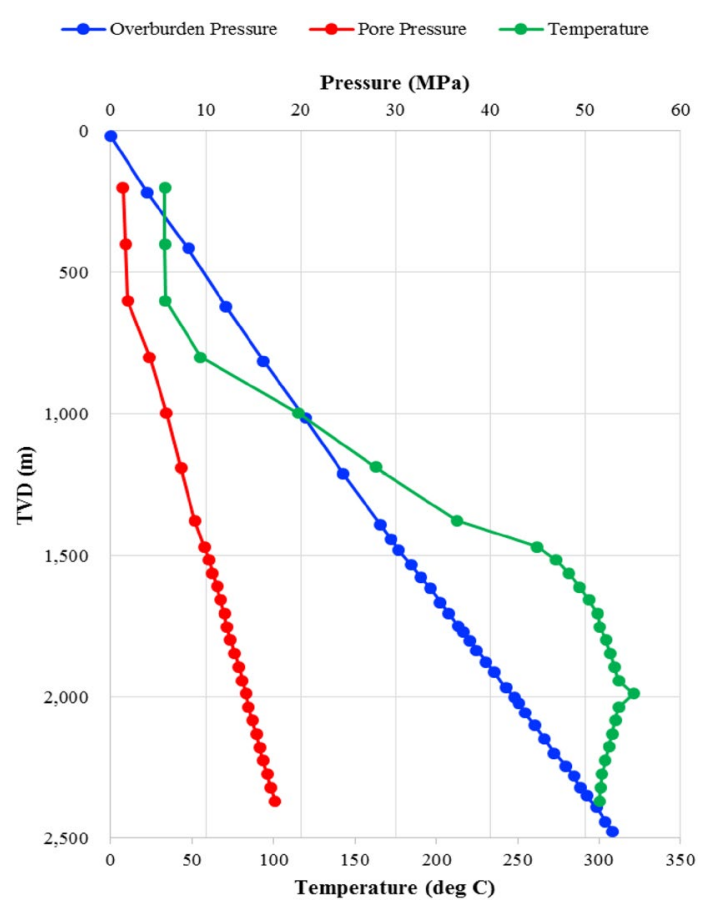

Fig. 5 Initial pressure and temperature survey of well HCE28B (PT Geo Dipa Energi 2019)

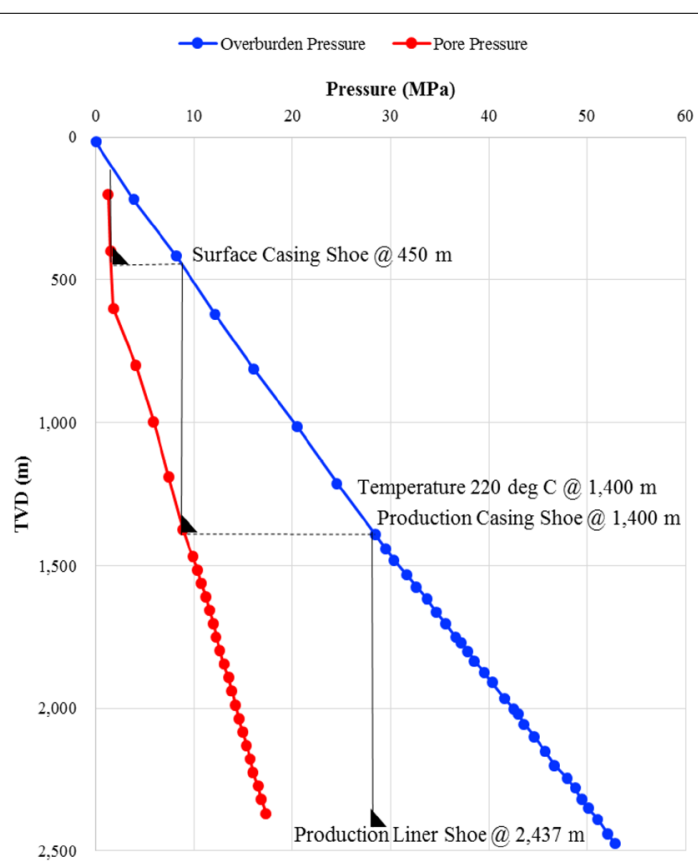

Fig. 6 Casing setting depth of well HCE28B

Table 3 shows the comparison of the actual and the proposed casing setting depth. The actual production casing shoe for the two wells was set deeper than the proposed depth, where the shoe had penetrated the high-temperature formation fluid. Consequently, the 
Table 3 Actual vs proposed casing setting depth

\begin{tabular}{llllll}
\hline Section & Well HCE9B & & Well HCE28B & \\
\cline { 2 - 3 } & Actual (m TVD) & Proposed (m TVD) & & Actual (m TVD) & $\begin{array}{c}\text { Proposed } \\
\text { (m TVD) }\end{array}$ \\
\hline $\begin{array}{c}\text { Surface casing shoe } \\
(508 \mathrm{~mm})\end{array}$ & 454 & 450 & 440 & 450 \\
$\begin{array}{c}\text { Production casing } \\
\text { shoe }(339.7 \mathrm{~mm})\end{array}$ & 1519 & 1250 & 1504 & 1400 \\
\hline
\end{tabular}

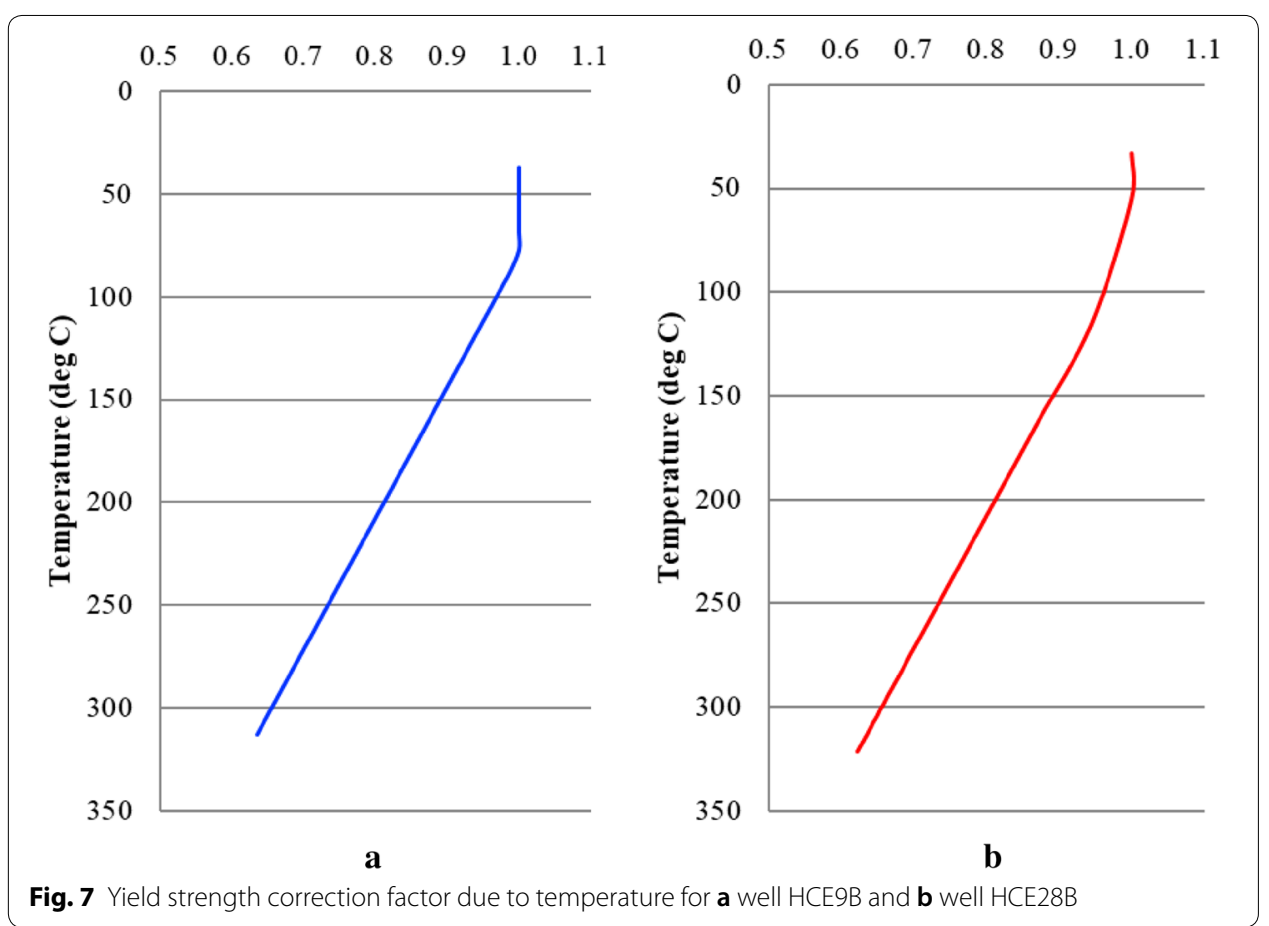

lower part of the production casing was exposed to the higher temperature load and caused casing strength decrease which might have led to casing failure.

\section{Casing load evaluation}

The casing collapse, burst, and tension load were recalculated by considering a hightemperature effect. The static temperature data were used in the calculation (Fig. 4). Figure 7 shows the result of yield strength correction factor calculation due to temperature effect (Marbun 2013). The burst, collapse, and tension rating of the production casing were then corrected according to the calculated correction factor. The yield strength correction factor was calculated based on the following equation:

$$
\frac{\sigma}{\sigma_{\text {yield }}}=1-\frac{(T-80)}{640}
$$

where $\sigma=$ casing stress $(\mathrm{MPa}), \sigma_{\text {yield }}=$ yield strength $(\mathrm{MPa}), T=$ well temperature $\left({ }^{\circ} \mathrm{C}\right)$.

If the temperature of the well is below $80^{\circ} \mathrm{C}$, then $\frac{\sigma}{\sigma_{\text {yield }}}=1$. 


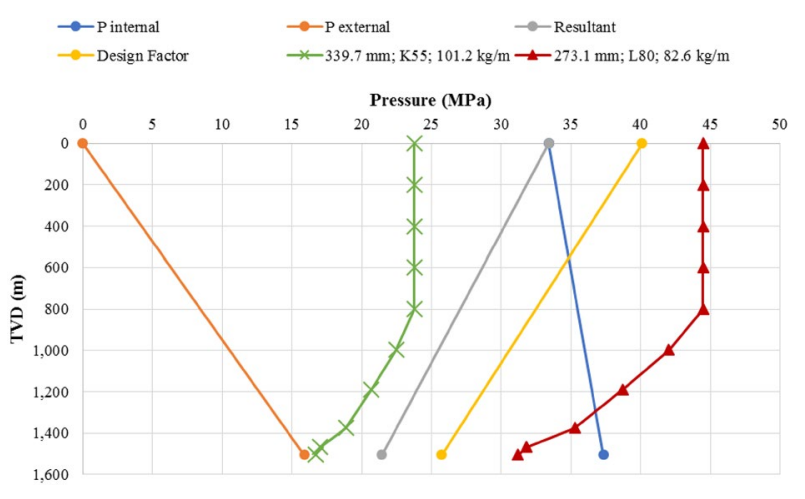

Fig. 8 Burst load for production casing and tieback casing of well HCE28B

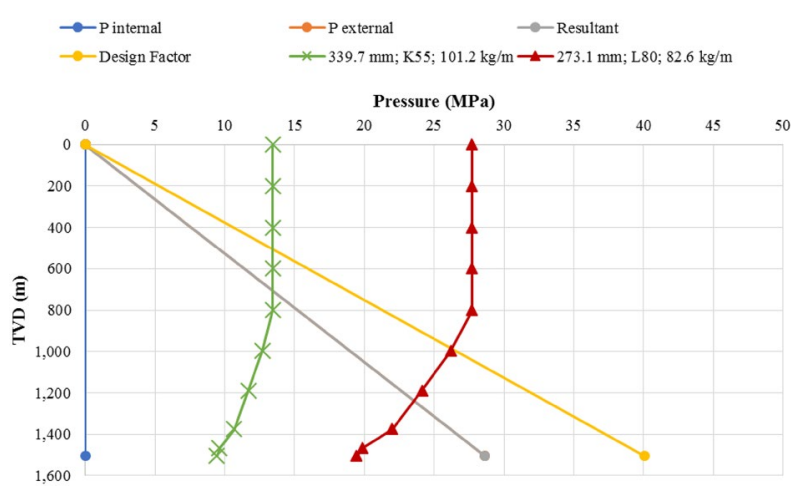

Fig. 9 Collapse load for production casing and tieback casing of well HCE28B

The burst, collapse, and tension load of casing of wells HCE9B and HCE28B were calculated based on maximum load scenario of oil and gas method. The burst scenario considered the cement pressure during cementing operation as internal pressure while the formation pressure acts as external pressure. The collapse scenario was considered the worst scenario during cementing operation, in which the hydrostatic cement pressure acts as external pressure and inside the casing is empty. The tension load of the casing was calculated based on the self-weight and buoyancy effect of the drilling fluid. The design factor applied to each load was 1.2, 1.4, and 2.2 for burst, collapse, and tension design, respectively (Hole 2006; Marbun 2013; Ngigi 2015). The temperature effect is incorporated through yield strength correction factor application in casing burst, collapse, and tension load recalculation.

Figures 8, 9 and 10 show the casing load recalculation of production casing and tieback casing in well HCE28B. The result of the recalculation showed that the production casing (K-55, $101.2 \mathrm{~kg} / \mathrm{m})$ in well HCE28B failed to withstand burst and collapse scenarios, which is indicated by the casing rating line crossing the resultant line. Sometimes, the tieback casing (L-80, $82.3 \mathrm{~kg} / \mathrm{m}$ ) in well HCE28B also failed to withstand the collapse scenario as indicated in Fig. 9. Nevertheless, there was no indication that the casing parted because the tension rating of the casing is higher than the 

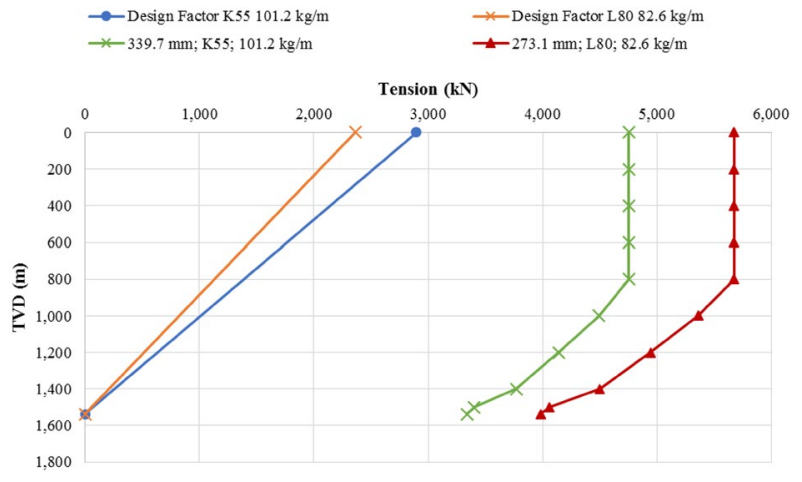

Fig. 10 Tension load for production casing and tieback casing of well HCE28B

resultant. It should be noted also that this analysis was made by assuming the casing was new and no thickness reduction. The calculation result for the two wells is summarized in Table 4. The casing design was recalculated based on the actual casing depth and grade installed in the two wells. Then, the calculated load design was compared with the burst, collapse, and tension rating of the casing. Based on load recalculation, casing failure, burst, and collapse were identified in the wells.

According to the casing design analysis, it is confirmed that improper production casing design of burst and collapse was one of the causes of casing failure in the two abandoned wells. Tension rating of production casings is accepted.

\section{Result of casing failure evaluation based on evaluation of inclination and azimuth angle effect}

Dogleg severity analysis (DLS) was performed to estimate precisely the real casing failure location and potential of the damage severity. In directional wells, DLS causes secondary stress to the casing, which is known as bending (Nicholson 1984). The bending could induce tension to the lower side of the casing, as well as compression to the upper side. In geothermal wells, such stresses are also affected by the high static and dynamic temperature during the life of the wells. When a well is shut-in, the casing will be heated up and compressed due to the expansion effect. As the well is produced, additional compression would be induced in the casing due to the discharge force of the steam. Such conditions can lead to casing fatigue and deformation, particularly at the high DLS zone (Marbun et al. 2015).

A dogleg severity analysis of the wells HCE9B and HCE28B from directional survey data was performed. The data show that some depths in the two abandoned wells have DLS above $2 \% / 30 \mathrm{~m}$, even up to $4^{\circ} / 30 \mathrm{~m}$ (Fig. 11). In oil and gas industry best practice, $3^{\circ} / 30 \mathrm{~m}$ is usually considered as the maximum allowable DLS that can prevent problems during the next operation stage, such as casing running. Considering the wells were originally drilled in the extreme geothermal environment (i.e.. hard rocks, high temperature, etc.) with methodology and equipment according to the oil and gas approach, $2 \% / 30 \mathrm{~m}$ is used as a rough limit assumption to distinguish the high DLS zones (Hole 2006). Both the wells have the potential to experience casing failure at depth intervals with high DLS. Casing failure in well HCE9B might occur at the interval with high DLS at 870-1186 m 


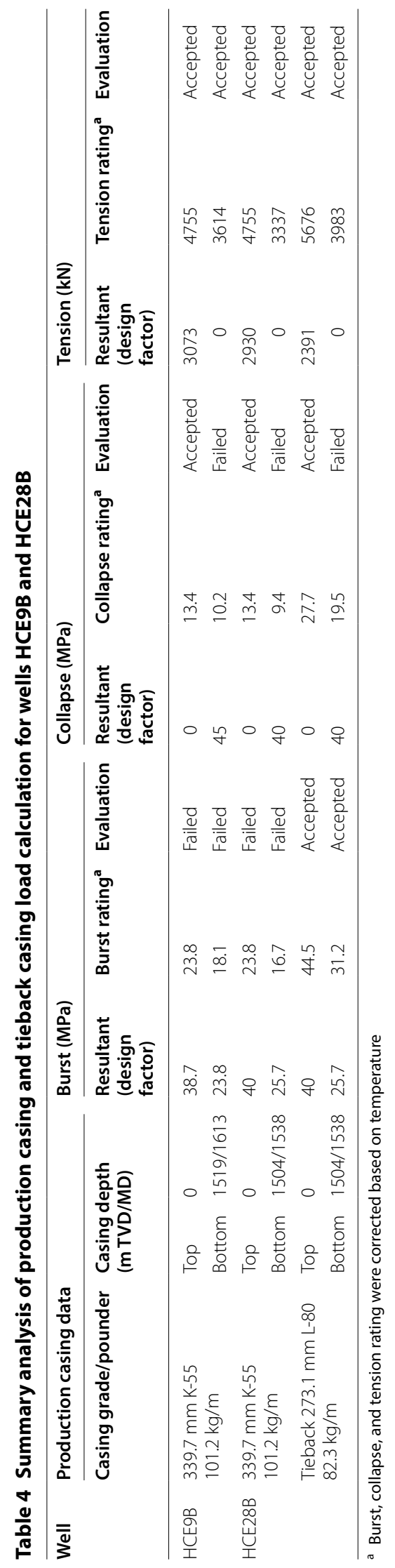




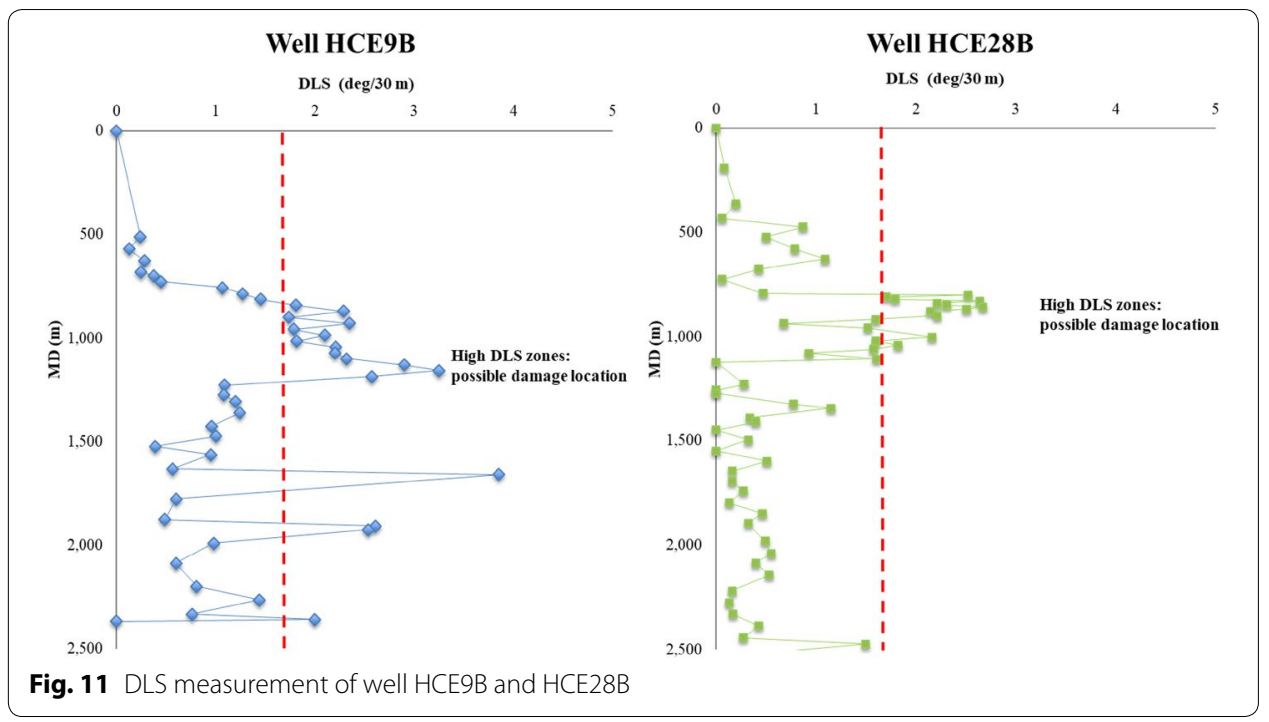

Table 5 Mandatory aspects in designing geothermal well in Field Dieng

\begin{tabular}{lll}
\hline No. & $\begin{array}{l}\text { Flow paths of wellbore drilling design and integrity based on common SOP and best } \\
\text { engineering practice }\end{array}$ & Mandatory \\
\hline 1. & Casing setting depth_Philippines' method (temperature $220^{\circ} \mathrm{C}$, fluid is water dominant) & $\checkmark$ \\
2. & Casing design - strength correction due to high thermal effect & $\checkmark$ \\
3. & Casing grade selection with high thermal effect consideration & $\checkmark$ \\
4. & Proper data storage and management & $\checkmark$ \\
5. & Proper directional drilling design and operational & $\checkmark$ \\
\hline
\end{tabular}

MD, 1631-1657 m MD, and 1905-1923 m MD. Casing failure in well HCE28B might occur at the interval with high DLS at 801-899 m MD and 957-1002 m MD.

One of the causes of high DLS in the two abandoned wells was that wells experienced hole instability problems during the drilling operation. Moreover, wells HCE9B and HCE28B had to be sidetracked due to stuck pipe problems. Well HCE9B was sidetracked twice at $1617 \mathrm{~m} \mathrm{MD}$ and $1615 \mathrm{~m}$ MD, while well HCE28B was sidetracked at $1300 \mathrm{~m}$ MD.

\section{Discussion and proposed well intervention and workover plan}

Prior to reactivation of the abandoned geothermal well, well intervention and workover operation to repair the casing and cement to maintain the sustainability of future steam production have to be performed. The analysis performed in this study showed that casing failure likely occurred in the wells. According to the investigation performed in this study, common SOP and best engineering practice of geothermal drilling were not carried out in the casing design and drilling operations. Table 5 shows the summary of flow paths of wellbore drilling design and integrity based on common SOP and best engineering practice in designing geothermal casing (Standards New Zealand 1991; Hossein-Pourazad 2005; Sarmiento 2007; Marbun et al. 2013, 2015; Nicholson 1984). This lesson learned can also be applied to the other similar geothermal wells, particularly for future geothermal wells 
drilling in this field. Based on the numerical analysis (e.g., casing setting depth and casing design analysis by considering the high-temperature effect, DLS analysis), the casing damaged and damage location in the abandoned geothermal wells could be predicted. However, a complete well intervention and workover program could not be developed yet due to inadequate data and information caused by the wellbore plugging issue. Based on industry best practice approach and technical evaluation of the wells in the field, mechanical cleaning should be performed first to clear the obstruction due to silica scaling.

Mechanical cleaning would be the most effective well intervention and workover method to clear the obstructions and to get access to the feed zone, as this method can be run simultaneously to drill out the silica scale and mill out any casing collapse. Further, after gaining access to the total depth of the well, investigation of casing and cement integrity should be performed to assess the well before recommencing the production. Caliper log can be run to investigate the casing thickness reduction and casing collapse. To get a more robust investigation, a pressure, temperature, and spinner (PTS) log should be run after running the caliper log to investigate the leak zones. However, running the caliper and PTS log can be risky if the casing failure is severe (deformation, buckling, torn, etc.) due to the risk of being stuck. Thorough risk identification should be prepared before commencing the well intervention and workover operation. The downhole video (DHV) would be effective in identifying the problem as it can visualize the wellbore condition in real time (Thorhallsson 2003). Casing and cement sheath evaluation log (e.g., production log, CBL, VDL, etc.) should also be performed to investigate the wellbore's integrity. If the cement sheath evaluation shows cement damage and/or the PTS log confirms and locates the leak zones, remedial cementing (e.g., squeeze cementing, etc.) for the existing production casing need to be considered. This is to isolate the well from the cement or formation behind the existing production casing. If not, the leakage could potentially damage the tieback casing and cement in the future (Thorhallsson 2003).

If the caliper log confirms a severe reduction of casing thickness or casing deformation, the tieback casing could be an option (Thorhallsson 2003). In well HCE9B, $244.5 \mathrm{~mm}$ tieback casing can be cemented above $244.5 \mathrm{~mm}$ liner. If casing failure is also found in a $244.5 \mathrm{~mm}$ liner, there is still an option to tieback the $177.8 \mathrm{~mm}$ liner. In well HCE28B, there is a limitation to tieback the $244.5 \mathrm{~mm}$ liner, since there was a $219.1 \mathrm{~mm}$ scab liner installed on $273 \mathrm{~mm}$ casing. Installing another scab liner smaller than $219.1 \mathrm{~mm}$ would be an option. However, if the casing failure occurred along the $273 \mathrm{~mm}$ casing, running and cementing $177.8 \mathrm{~mm}$ long string casing to the top of $244.5 \mathrm{~mm}$ is recommended.

Practically, hydraulic workover unit (HWU) is adequate to perform mechanical cleaning and well investigation (e.g., logging, DHV, etc.). However, in the case that tieback casing and/or remedial cementing is required to repair the production casing, a workover rig is required. The utilization of one workover rig for all the required workover operations (i.e., mechanical cleaning, well investigation, casing repair and remedial cementing) is considered to optimize the cost.

\section{Conclusion}

The study presents crucial challenges including casing failure evaluation since the wells were formerly designed without fully considering extreme geothermal environment (e.g., high temperature, etc.) and not following the general geothermal SOP or best 
engineering practice. Another limitation was the limited official available data which brought difficulty in the study. However, the recent well condition including the casing failure has been assessed and evaluated based on analysis of casing setting depth, casing design, inclination and azimuth angle effect, last well intervention and workover data, and other engineering approaches with high thermal effect consideration.

Based on numerical analysis, casing failure, burst, and collapse as indicated in the two abandoned wells, the casing setting depth analysis, casing load recalculation, and inclination and azimuth angle effect analysis showed casing failure and predicted damage location in those wells. Despite the limitation of official information and data, the result of the study helped PT Geo Dipa Energi to ascertain the current wells' condition, to define further decision of reactivating the abandoned well. The well intervention and workover plan can be designed properly according to the result presented in this study. The methodology established in this study can also be applied to other similar geothermal wells in Field Dieng, either to abandoned wells or future well drilling.

\section{Abbreviations}

CBL: Cement bond log, mV; CSG: Casing; DHV: Downhole camera; DLS: Dogleg severity, /30 m; $\mathrm{H}_{2} \mathrm{~S}$ : Hydrogen sulfide; HWU: Hydraulic workover unit; PT: Pressure and temperature; PTS: Pressure, temperature, and spinner; MD: Measured depth, m; TVD: True vertical depth, m; TOL: Top of liner; VDL: Variable density log, $\mu \mathrm{s} ; \mathrm{SiO}_{2}$ : Silicon dioxide; SOP: Standard operating procedure; XRD: X-ray diffraction.

\section{Acknowledgements}

The authors would like to express their sincere gratitude to PT Geo Dipa Energi for giving permission to publish this project.

\section{Authors' contributions}

RHR provided the data. BTHM provided the structure, direction, and methodology of the research, performed data calculation, including data analysis and interpretation, and prepared manuscript content and approval. BTHM, SZS, BP, and BAP performed calculation and prepared the manuscript draft. All authors read and approved the final manuscript.

\section{Funding}

Not applicable.

\section{Availability of data and materials}

The data that support the findings of this study are available from PT Geo Dipa Energi but restrictions apply to the availability of these data, which were used under license for the current study, and so are not publicly available. Data are however available from the authors upon reasonable request and with permission of PT Geo Dipa Energi.

\section{Competing interests}

The authors declare that they have no competing interests.

Author details

${ }_{1}^{1}$ Petroleum Engineering Study Program, Bandung Institute of Technology, Jalan Ganesha 10, Bandung 40132, Indonesia.

2 PT Geo Dipa Energi, Jakarta, Indonesia.

Received: 23 April 2019 Accepted: 21 September 2019

Published online: 16 October 2019

\section{References}

Agustinus ETS, Syafri I, Rosana MF, Zulkarnain I. Scale prevention technique to minimized scaling on re-injection pipes in Dieng geothermal field, Central Java Province, Indonesia. Indonesian J Geosci. 2018;5:129-36.

Asian Development Bank and The World Bank. Unlocking Indonesia's geothermal potential. Philippines, 85. 2015. https ://www.adb.org/sites/default/files/publication/157824/unlocking-indonesias-geothermal-potential.pdf. Accessed June 2019.

Capuano LE Jr. Geothermal well drilling. Chap. 5. In: DiPippo R, editor. Geothermal power generation-developments and innovation. Amsterdam: Elsevier; 2016. p. 107-39. https://doi.org/10.1016/C2014-0-03384-9.

Caulk RA, Tomac I. Reuse of abandoned oil and gas wells for geothermal energy production. Renew Energy. 2017;112:388-97. https://doi.org/10.1016/j.renene.2017.05.042.

Darma S. Indonesia: vast geothermal potential, modest but growing exploitation. Chap. 21. In: DiPippo R, editor. Geothermal power generation-developments and innovation. Amsterdam: Elsevier; 2016. p. 609-43. https://doi. org/10.1016/C2014-0-03384-9. 
Dench ND. Casing string design for geothermal wells. Geothermics. 1970;2:1485-96. https://doi.org/10.1016/03756505(70)90468-2.

Hole H. Directional drilling of geothermal wells. Okustofnun: United Nations University, Geothermal Training Programme, National Energy Authority; 2006.

Hossein-Pourazad H. High-temperature geothermal well design. Reykjavik: The United Nations University Geothermal Training Programme; 2005.

Kaldal GS, Jonsson MT, Palsson H, Karlsdottir SN. Structural modeling of the casings in high temperature geothermal wells. Geothermics. 2015;55:126-37. https://doi.org/10.1016/j.geothermics.2015.02.003.

Marbun BTH. Wellbore problem identification and workover feasibility study of geothermal field Dieng Indonesia, PT Geo Dipa Energi. Bandung: Bandung Institute of Technology; 2013.

Marbun B, Aristya R, Pinem RH, Ramli BS, Gadi KB. Evaluation of non productive time of geothermal drilling operations - case study in Indonesia. In: Thirty-eighth workshop on geothermal reservoir engineering. Stanford: Stanford University. 2013. https://pangea.stanford.edu/ERE/pdf/IGAstandard/SGW/2013/Marbun4.pdf. Accessed June 2019.

Marbun BTH, Purba NP, Fadholi BZ. An integrated management of drilling design and operational of geothermal wells. Melbourne: World Geothermal Congress; 2015.

McGee LE, Smith IEM. Interpreting chemical compositions of small scale basaltic systems: a review. J Volcanol Geotherm Res. 2016;325:45-60. https://doi.org/10.1016/j.jvolgeores.2016.06.007.

Ngigi AN. Geothermal well design using the new 2015 New Zealand Standard and 1991 Standard: a case of MW-20A in Menengai, Nakuru County, Kenya. Reykjavik: Geothermal Training Programme, United Nations University. 2015. https ://orkustofnun.is/gogn/unu-gtp-report/UNU-GTP-2015-28.pdf. Accessed June 2019.

Nian Y, Cheng W. Evaluation of geothermal heating from abandoned oil wells. Energy. 2018a;142:592-607. https://doi. org/10.1016/..energy.2017.10.062.

Nian Y, Cheng W. Insights into geothermal utilization of abandoned oil and gas wells. Renew Sustain Energy Rev. 2018b;87:44-60. https://doi.org/10.1016/j.rser.2018.02.004.

Nicholson RW. Casing design for temperature regimes in geothermal wells. Geotherm Resour Council Bull. 1984;13:23-6.

Pellet FL. Rock mechanics is meeting the challenge of geo-energies. Procedia Eng. 2017;191:1104-7. https://doi. org/10.1016/j.proeng.2017.05.284.

PT Geo Dipa Energi. Internal Report. Company Internal Report. Jakarta: Geo Dipa Energi; 2019.

Purwaningsih FO, Husnie R, Afuar W, Abdurrahman G. Make-up wells drilling cost in financial model for a geothermal project. In: 6th ITB international geothermal workshop (ilGW2017). Bandung: Bandung Institute of Technology. 2017. https://doi.org/10.1088/1755-1315/103/1/012010. Accessed June 2019.

Røksland M, Basmoen TA, Sui D. Geothermal energy extraction from abandoned wells. Energy Procedia. 2017;105:244-9. https://doi.org/10.1016/j.egypro.2017.03.309.

Sarmiento ZF. A snapshot of the drilling and completion practices in high temperature geothermal wells in the Philippines. In: Workshop 4 of the Engine "Drilling cost effectiveness and feasibility of high-temperature drilling. Reykjavik, Iceland. 2007.

Sirait P, Ridwan RH, Battistelli A. Reservoir modeling for development capacity of Dieng geothermal field, Indonesia. In: Fortieth workshop on geothermal reservoir engineering. Stanford: Stanford University. 2015. https://pangea.stanf ord.edu/ERE/db/IGAstandard/record_detail.php?id=20582. Accessed June 2019.

Southon J. Geothermal well design, construction and failures. In: World geothermal congress 2005. Antalya, Turkey. 2005. Standards New Zealand. Code of practice for geothermal wells. Wellington: Standard Association of New Zealand; 1991.

Thorhallsson S. Geothermal well operation and maintenance. Reykjavík: The United Nations University Geothermal Training Programme; 2003.

Thorhallsson S. Common problems faced in geothermal generation and how to deal with them. In: Workshop for decision makers on geothermal projects in Central America. San Salvador, El Savador. 2006.

von Hirtz P. Silica scale control in geothermal plants-historical perspective and current technology. Chap. 16. In: DiPippo R, editor. Geothermal power generation: developments and innovation. Amsterdam: Elsevier; 2016. p. 443-76. https ://doi.org/10.1016/C2014-0-03384-9.

Wahjosoedibjo AS, Hasan M. Indonesia's geothermal development: where is it going? In: 43rd workshop on geothermal reservoir engineering. Stanford, California: Stanford University. 2018. https://pangea.stanford.edu/ERE/pdf/IGAst andard/SGW/2018/Hasan.pdf. Accessed June 2019.

Wahyudityo R, Harto AW, Suryopratomo K. Analisis Scaling Silika pada Pipa Injeksi Brine di Lapangan Panas Bumi Dieng dengan Studi Kasus di PT. Geo Dipa Energi. Teknofisika. 2013;2(1):7-14.

\section{Publisher's Note}

Springer Nature remains neutral with regard to jurisdictional claims in published maps and institutional affiliations. 